\title{
Blood pressures higher in the home than in the clinic in rural Kenya
}

\author{
N R POULTER, ${ }^{*}$ J D LURY, ${ }^{2}$ AND A V THOMPSON ${ }^{2}$ \\ From the Department of Medicine, ${ }^{1}$ St Mary's Hospital, London, and University of Nairobi, Kenya; and the \\ Wellcome Trust Research Laboratories, ${ }^{2}$ Nairobi, Kenya
}

SUMMARY The conditions under which blood pressures (BPs) are recorded are critical, and it has been demonstrated several times that BPs measured in the home are lower than those measured in the clinic. ${ }^{1}$ However, these comparisons are based on home BPs measured by the patients or their friends and relatives and clinic BPs measured by doctors and nurses. To our knowledge, no comparison of home and clinic BPs measured by the same observer has been reported, and we present the results of such a study which is the first to demonstrate higher BPs in the home environment, perhaps reflecting the unacculturated nature of the study population.

\section{Subjects, methods and results}

As part of a longitudinal BP survey, ${ }^{2} 38$ members of a rural, unacculturated, low-BP community in Western $\mathrm{Kenya}^{3}$ were studied in one of three local schools. Details of this examination are reported elsewhere ${ }^{2}$ but include two BP measurements using a random zero sphygmomanometer ${ }^{4}$ after patients had been lying down for at least 5 minutes. Diastolic BPs were recorded at phase $V$. During the ensuing three days, 33 of these 38 rural subjects were located and examined again in their homes by the same observer using the same methods (five subjects had temporarily left the study area). Measurements common to the two examinations were: ambient temperature, time of day, electrolyte content of a casual urine sample, two lying BPs, and one radial pulse rate. The table shows the mean values of these variables in the schools (clinic) and in the home for the group as a whole and by sex. Systolic and diastolic BPs are higher in the home and significantly so for the systolic BPs of females and the whole group $(\mathrm{p}<0.025$ and $<0.05$ respectively). The ambient temperature was slightly higher in the home, and the home BPs were measured later in the day. These differences were significant for the men $(\mathrm{p}<0.025$ and $<0.005$ respectively) and for the group as a whole ( $p<0.025$ and $<0.005$ respectively) but were not significant for the females. Student's $t$ test for paired data was used in the analysis.

-Correspondence to: Dr N R Poulter, Clinical Pharmacology, St Mary's Hospital, Praed Street, London W2.
Clinic and home measurements of blood pressure and other selected variables, by sex

\begin{tabular}{|c|c|c|c|c|c|c|}
\hline & \multicolumn{2}{|l|}{$\begin{array}{l}\text { Males } \\
(n=14)\end{array}$} & \multicolumn{2}{|l|}{$\begin{array}{l}\text { Females } \\
(n=19)\end{array}$} & \multicolumn{2}{|c|}{$\begin{array}{l}\text { Males }+ \text { Females } \\
(n=33)\end{array}$} \\
\hline & Clinic & Home & Clinic & Home & Clinic & Home \\
\hline Systolic BP & 112.9 & $114 \cdot 1$ & $107 \cdot 3$ & $111 \cdot 5^{* *}$ & $109 \cdot 7$ & $112.6^{*}$ \\
\hline $\begin{array}{c}\left(\mathbf{m m} \mathbf{H}_{\mathbf{g}}\right) \\
\text { Diastolic BP }\end{array}$ & $\begin{array}{c}(10.9) \\
54.6\end{array}$ & $\begin{array}{l}(8 \cdot 3) \\
56.8\end{array}$ & $\begin{array}{l}(8 \cdot 1) \\
58 \cdot 8\end{array}$ & $\begin{array}{l}(8.6) \\
61.4\end{array}$ & $\begin{array}{l}(9.7) \\
57.1\end{array}$ & $\begin{array}{l}(8.4) \\
59.4\end{array}$ \\
\hline (mm Hg) & $\begin{array}{l}54 \cdot 0 \\
(7 \cdot 5)\end{array}$ & $\begin{array}{c}50 \cdot 8 \\
(11 \cdot 3)\end{array}$ & $\begin{array}{l}58 \cdot 8 \\
(9 \cdot 2)\end{array}$ & $\begin{array}{l}61 \cdot 4 \\
(9 \cdot 2)\end{array}$ & $\begin{array}{l}57 \cdot 1 \\
(8 \cdot 7)\end{array}$ & $\begin{array}{c}59 \cdot 4 \\
(10 \cdot 2)\end{array}$ \\
\hline $\begin{array}{l}\text { Heart rate } \\
\text { (beats } / \mathrm{min} \text { ) }\end{array}$ & $\begin{array}{c}66.9 \\
(10.8)\end{array}$ & $\begin{array}{c}63.0 \\
(10.5)\end{array}$ & $\begin{array}{l}66 \cdot 1 \\
(7 \cdot 6)\end{array}$ & $\begin{array}{l}65 \cdot 6 \\
(7 \cdot 0)\end{array}$ & $\begin{array}{l}66.4 \\
(8 \cdot 9)\end{array}$ & $\begin{array}{l}64 \cdot 5 \\
(8 \cdot 6)\end{array}$ \\
\hline Ambient temp & $26 \cdot 2$ & $28 \cdot 0 *$ & $27 \cdot 2$ & 27.6 & $26 \cdot 8$ & $27 \cdot 8^{* *}$ \\
\hline$\left({ }^{\circ} \mathrm{C}\right)$ & $(1 \cdot 5)$ & $(1 \cdot 5)$ & $(1.4)$ & $(1 \cdot 8)$ & $(1 \cdot 5)$ & $(1 \cdot 7)$ \\
\hline Time of study (h) & 11.4 & $14 \cdot 5^{* * *}$ & 11.8 & $13 \cdot 3$ & 11.6 & $13 \cdot 8^{* * *}$ \\
\hline $\mathrm{Na} / \mathrm{K}$ of & 2.91 & 2.07 & 1.81 & 1.73 & $\begin{array}{l}1 \cdot 0) \\
2 \cdot 28\end{array}$ & $1 \cdot 88$ \\
\hline casual urines & $(3 \cdot 04)$ & $(1 \cdot 80)$ & $(1 \cdot 58)$ & $(1 \cdot 59)$ & $(2 \cdot 33)$ & $(1.66)$ \\
\hline
\end{tabular}

Mean values ( \pm SDs) of variables measured in the clinic and at home $\mathrm{Na}=$ sodium

$\mathbf{K}=$ potassium

Clinic $v$ home:

$$
\begin{aligned}
* p & <0.05 \\
* * p & <0.025 \\
* * * & <0.005
\end{aligned}
$$

\section{Comment}

Although these black Kenyan subjects had been examined five times in clinics in the previous two years by the same white observer (during which time their mean BPs had fallen ${ }^{2}$ ), most of them had never entertained a white person in their homes. The rooms of the homes in which the examinations took place are very basic and small compared to the larger, open classrooms used at clinics. These two factors might reasonably be expected to cause increased 'stress' among the subjects (particularly the females) which 
could explain the higher BP levels in the home. There was, however, no rise in pulse rate associated with the higher home BPs to support this possible explanation. We have previously demonstrated a very limited variability in the dietary electrolyte intakes of this population, ${ }^{3}$ and we therefore assume that the BP differences are not due to any change in diet between BP readings, as supported by the urinary electrolyte results. The differences in time of study may in part contribute to the higher home BPs since BP is thought to rise slightly throughout the day, reaching a peak in the early evening, ${ }^{5}$ but the higher mean temperatures in the homes would, if anything, lower the BPs. Furthermore, the differences between the home and clinic temperatures and times of study were not statistically significant for the females, in whom BP differences were greatest.

It is, of course, not certain that similar results would be found in a more westernised society, and hence these data suggest possible difficulties in making a between-population comparison of BP levels despite apparently 'standardising' conditions of measurement. However, the study does demonstrate the importance of standardising BP measurement conditions within a study population and is, as far as we are aware, the first to show BP levels to be higher in the home than in a clinic environment.

This work was supported by the Wellcome Trust. Our thanks are due to the people of the Saradidi Rural Health Project for their cooperation.

\section{References}

'O'Brien E, Fitzgerald D, O'Malley K. Blood pressure measurement: current practice and future trends. $\mathrm{Br}$ Med J 1985; 290: 729-34.

' Poulter NR, Khaw KT, Hopwood BEC, Mugambi M, Peart WS, Sever PS. Determinants of blood pressure changes due to urbanisation-a longitudinal study. $J$ Hypertension, in press.

${ }^{3}$ Poulter N, Khaw KT, Hopwood BEC, Mugambi M, Peart WS, Rose G, Sever PS. Blood pressure changes and associated factors in a rural Kenyan community. Hypertension 1984; 6: 810-3.

4 Wright BM, Dore F. A random zero sphygmomanometer. Lancet 1970; i: 337-8.

${ }^{5}$ Richardson DW, Honour AJ, Fenton GW, Stott FH, Pickering GW. Variation in arterial pressure throughout the day and night. Clin Sci 1964; 26: 445. 